Article

\title{
Morphological and Agronomic Characterization of Spanish Landraces of Phaseolus vulgaris L.
}

\author{
Sugenith Arteaga ${ }^{1}$, Lourdes Yabor ${ }^{1,2}{ }^{2}$ José Torres $^{3}$, Eva Solbes ${ }^{3}$, Enrique Muñoz ${ }^{3}$, \\ María José Díez ${ }^{3}$, Oscar Vicente ${ }^{1}$ (D) and Monica Boscaiu ${ }^{4, *}$ \\ 1 Institute for Plant Molecular and Cell Biology (IBMCP, UPV-CSIC), Universitat Politècnica de València, \\ Camino de Vera s/n, 46022 Valencia, Spain \\ 2 Laboratory for Plant Breeding and Conservation of Genetic Resources, Bioplant Center, University of Ciego \\ de Avila, 69450 Ciego de Ávila, Cuba \\ 3 Institute for Conservation and Improvement of Valencian Agrodiversity (COMAV, UPV), Universitat \\ Politècnica de València, Camino de Vera s/n, 46022 Valencia, Spain \\ 4 Mediterranean Agroforestry Institute (IAM, UPV), Universitat Politècnica de València, Camino de Vera s/n, \\ 46022 Valencia, Spain \\ * Correspondence: mobosnea@eaf.upv.es; Tel.: +34-963-879-253
}

Received: 28 May 2019; Accepted: 3 July 2019; Published: 9 July 2019

check for updates

\begin{abstract}
Beans (Phaseolus vulgaris L.) originated on the American continent, specifically in the Mesoamerican zone, and their domestication took place independently in the Mesoamerican area and the Andean zone, giving rise to two well-differentiated genetic pools. It was also noted that the Andean wild populations originated from only a few thousand individuals from the Mesoamerican wild populations, which produced a great bottleneck in the formation of the Andean population. During centuries of cultivation in the Iberian Peninsula after its introduction in the 16th century, beans adapted to new environments, evolving numerous local landraces. Twenty-four local landraces of $P$. vulgaris from Spain were analyzed in the greenhouse during two consecutive seasons. From each genotype, five plants were grown and characterized for 17 quantitative and 15 qualitative traits using the International Board for Plant Genetic Resources (IBPGR) descriptors. Data were analyzed statistically by analysis of variance (ANOVA), principal component analysis (PCA), and cluster analysis. The results obtained indicate a high variability for most traits, especially those related to the yield and its components. The PCA and cluster analysis separated the landraces according to the color of the seed, the yield, and the pod and seed traits related to yield. Numerous traits exhibited interactions between the genotype and the environment. Most accessions reached higher yields in spring, in which solar radiation favors photosynthesis and, consequently, photoassimilation. The different response to the changing environment of the set of accessions studied in the present work is of great interest, and it can be exploited in breeding cultivars adapted to a broader range of environmental conditions.
\end{abstract}

Keywords: common bean; local landraces; germplasms bank; variability

\section{Introduction}

Common bean (Phaseolus vulgaris L.) is one of the most important legume crops. The world production of beans in 2017 was 57,496,465 tons, cultivated on 38,229,984 hectares. Asia is the continent with the highest production at 38,045,186 tons, and Europe is the continent with the lowest production at 2,305,846 tons. In the European Union, the countries with the highest production are France, Lithuania, and Spain with 370,050, 230,112, and 183,324 tons, respectively. Castilla y León is the community with the largest area and production of beans in Spain, followed by Galicia and Asturias [1]. 
According to archeological, botanic, historical, and linguistic data, Gepts and Debouck [2] deduced that the common bean originated in the area between northern Mexico and northeastern Argentina. Due to the wide distribution of its wild ancestor through Mesoamerica and South America, the species was domesticated in two separate areas, the Mesoamerican and the South Andean. This resulted in two different gene pools based on differences in the phaseolin seed protein [3], molecular markers [4-7], and morphological traits [2,8]. The Mesoamerican gene pool extends from Mexico through Central America to northern Colombia, whereas the Andean one covers Peru, Chile, Bolivia, and northern Argentina. However, more recently, Bitochi et al. [9] conducted a study to solve the ongoing debate on the origins of the common bean, by investigating the nucleotide diversity at five gene loci of a large sample that represents the entire geographical distribution of the wild forms of this species. Their results clearly indicate a Mesoamerican origin of the common bean and the occurrence of a bottleneck during the formation of the Andean gene pool.

The first varieties of $P$. vulgaris, corresponding to small-grain Mesoamerican genotypes, were introduced in Spain and Portugal around 1506 [10] and from South America around 1532 [11,12]. Later on, gradually, Andean genotypes of large grain were also introduced as new territories were explored in the New World [11]. This germplasm spread throughout the Spanish territory and adapted to new environments, in terms of temperature and cropping systems, especially in the north and northwest of the Iberian Peninsula, which is the area where the greatest genetic variability was found [13]. On the other hand, the cultivation of germplasm of both genetic stocks occurred in proximal areas, in small farms, which favored the genetic flow between them, contrary to the genetic isolation that existed in America. This led to recombination between both genetic stocks, resulting in new genetically intermediate forms with both Mesoamerican and Andean phenotypes. The Iberian Peninsula can be considered as a secondary center of diversification of this species since beans were cultivated here for centuries in different agrosystems [14]. Although commercial varieties largely displaced landraces, there are still farmers who grow them for self-consumption and sale in local markets, especially in the north and northwest of Spain, where there is a marked tradition of this crop.

A huge number of accessions of this crop were collected and conserved in germplasm banks, and its genetic diversity was assessed in many different studies. Some of the most important collections are stored at the Center for Tropical Agriculture (CIAT, Cali, Colombia), the Western Regional Plant Introduction Station, Pullman (Washington, USA), Institut für Pflanzengenetik und Kulturpflanzenforschung (IPK, Gatersleban, Germany), and the Vavilov Institute of Plant Industry (VIR, Russian Federation) [15]. In Spain, there are several institutions conserving accessions of the genus Phaseolus. The most important one is maintained in the Spanish Center for Genetic Resources, (CRF, Alcalá de Henares, Madrid), followed by the Biological Mission of Galicia (MBG, Pontevedra), the Agricultural Technology Institute of Castilla y León (ITACyL, Valladolid), the Agrifood Research and Technology Center of Aragon (CITA, Zaragoza), and the Institute of Conservation and Improvement of the Valencian Agrodiversity (COMAV, Polytechnic University of Valencia).

Average yields of common beans, as for practically all major crops, are much below $20-50 \%$ of their record yields, mostly due to abiotic stress factors, such as drought, soil salinization, or extreme temperatures, among others [16]. The forecasted effects of global warming are mostly longer and more frequent periods of drought, heat waves, and irregular meteorological patterns. They are already noticed in large areas of the world, including the Mediterranean [17]. These factors, in combination with the shortage of water available for irrigation, will probably increase the losses in agricultural production. Commercial varieties, generally selected on criteria related to their yields or tolerance to pests and parasites, are generally sensitive to abiotic stress. One of the challenges of modern agriculture is the use of genotypes more tolerant to drought and salinity; therefore, the screening of neglected varieties and local landraces stored in germplasm banks acquires a special relevance [18]. Phenotyping common beans for adaptation to abiotic stress, and analysis of its physiological mechanisms of response to stress were the object of numerous studies in the last decade [19-21], among many others. Similar comparative studies were performed by our group on different species of Phaseolus [22-24]. In this 
work, we present an exhaustive morphological characterization of 24 accessions of common bean local landraces stored at the seed bank of COMAV; they were chosen, maximizing their geographical origin and their morphological diversity, for studying their adaptation to drought and salinity (manuscript in preparation). The study of the phenotypic traits is essential to know the agronomic potential of these landraces and their use in plant breeding. The high variability found for morphological and agronomic traits in the different types of bean studied is remarkable and makes this set of accessions of great interest for their use in breeding.

\section{Materials and Methods}

\subsection{Seed Material}

Twenty-four local landraces of $P$. vulgaris from Spain were characterized for two consecutive growing seasons, in autumn and spring. Accessions were collected in the 1990s directly from growers. The origin of the analyzed accessions with their reference codes is indicated in Figure 1.

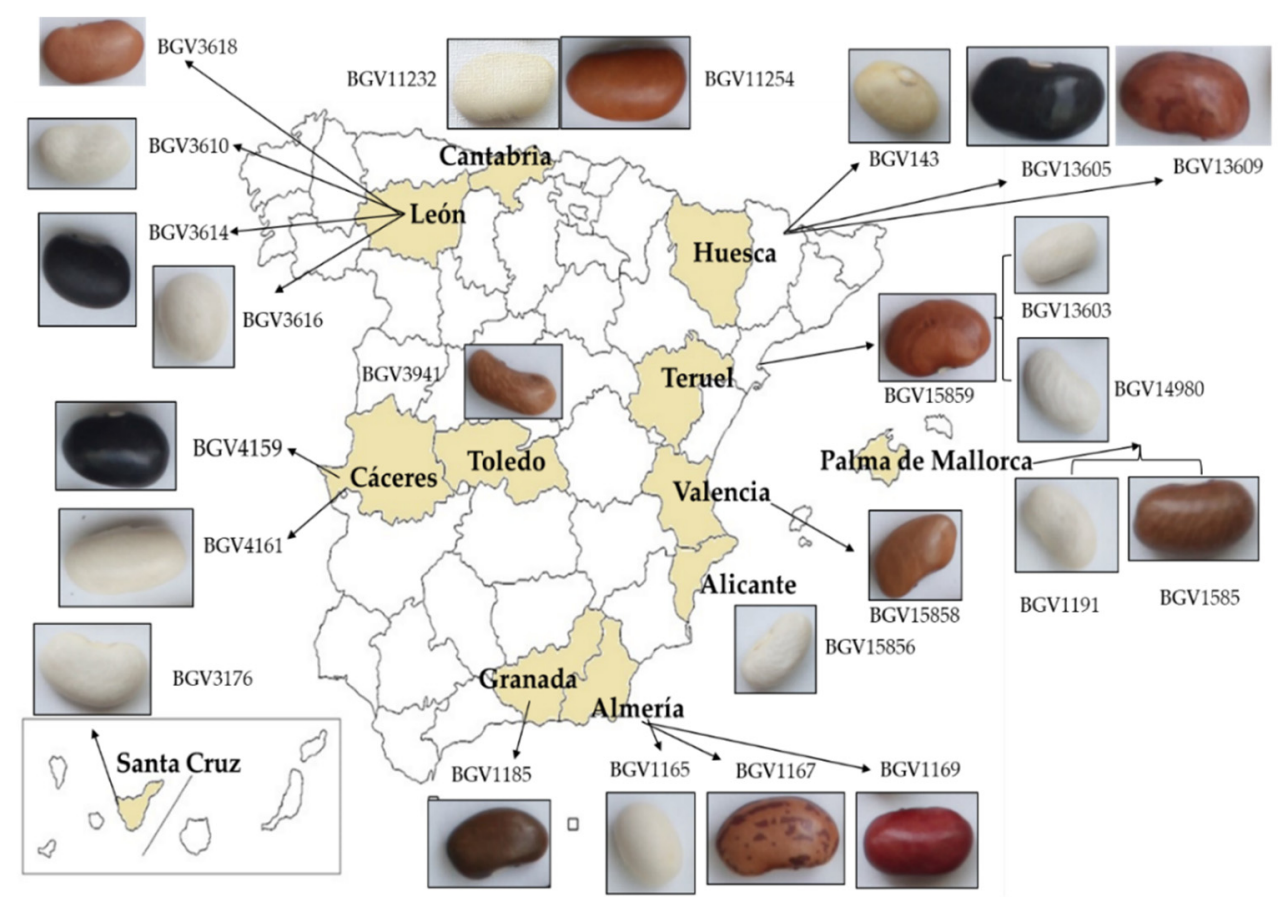

Figure 1. Geographic origin of the 24 Phaseolus vulgaris cultivars.

Six seeds of each genotype were germinated in individual pots of $1.6 \mathrm{~L}$. Once plants formed the first three trifoliate true leaves and reached a minimum of $20 \mathrm{~cm}$ in height, they were transplanted to pots of $7 \mathrm{~L}$ on a substrate with peat-perlite-vermiculite (2:1:1) in the greenhouse. The experimental design included five individuals from each accession in one plot, with sufficient separation between them. Watering was carried out by drip irrigation with Hoagland solution provided by the greenhouse. The average temperature during the trial carried out in autumn was $20.3{ }^{\circ} \mathrm{C}$ (ranging from 15.9 to $24.1^{\circ} \mathrm{C}$ ), the relative humidity was $86.85 \%$, and the solar radiation was $38.4 \mathrm{~W} \cdot \mathrm{m}^{2}$. In spring, the average temperature was $20.4{ }^{\circ} \mathrm{C}\left(15.3-24.1^{\circ} \mathrm{C}\right)$, relative humidity was $84.41 \%$, and radiation $85.5 \mathrm{~W} \cdot \mathrm{m}^{2}$ (Figure 2).

\subsection{Descriptors Used for the Agronomic Characterization}

During the two cycles of growth, 17 quantitative and 15 qualitative traits related to vegetative characteristics, flowers, pods, and seeds were recorded (Table 1). The descriptors developed by the International Board for Plant Genetic Resources (IBPGR) were used [25]. This descriptor list was 
prepared by IBPGR in a standard format following the advice of crop experts throughout the world. Five plants, and five pods and ten seeds from each plant were analyzed for each genotype in each cycle. Pods were collected when they were completely ripe. Productivity was calculated by multiplying the number of pods per plant by the number of seeds per pod and by the average weight of one seed.

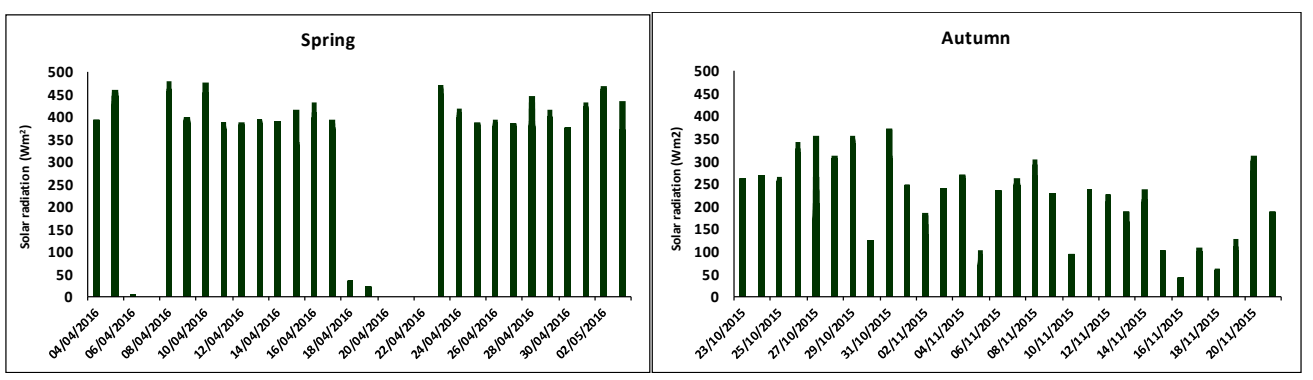

Figure 2. Solar radiation registered in the greenhouse during the autumn (a) and spring trials (b).

Table 1. Quantitative and qualitative traits in the 24 Phaseolus vulgaris accessions. IBPGR-International Board for Plant Genetic Resources.

\begin{tabular}{|c|c|c|}
\hline Descriptor IBPGR [25] & Acronym & Unit/Scores \\
\hline \multicolumn{3}{|r|}{ Quantitative } \\
\hline \multicolumn{3}{|r|}{ Vegetative } \\
\hline 4.1.1. Leaflet length & (LeafL) & Measured on the terminal leaflet of third trifoliate leaf from pulvinus to leaf tip $(\mathrm{cm})$ \\
\hline Width of the central sheet *** & (Wcshe) & Measured on the terminal leaflet of the third trifoliate leaf $(\mathrm{cm})$ \\
\hline 6.1.1. Hypocotyl length & (HypL) & Average length in $\mathrm{cm}$, from 5 plants. Measured when primary leaves were fully expanded \\
\hline 6.1.9. Plant height & (PlantH) & Average height, in $\mathrm{cm}$, at maturity, from 5 plants. Measured from cotyledon scar to tip of the plant \\
\hline 6.1.10. Stem diameter & (StemD) & Measured in mm at maturity for plants at crop density \\
\hline \multicolumn{3}{|r|}{ Inflorescence and pod } \\
\hline 4.2.2. Days to flowering & (Dflow) & Number of days from emergence to the stage where $50 \%$ of plants have set flowers \\
\hline $\begin{array}{l}\text { 4.2.3. Flower buds } \\
\text { per inflorescence }\end{array}$ & (FlowBI) & Average number of flower buds from 5 plants, examining one inflorescence from each plant \\
\hline 4.2.7. Pod length & (PodL) & Average length, in $\mathrm{cm}$, of the largest fully expanded immature pod \\
\hline 6.2.9. Inflorescence length & (InfloL) & Average length, in cm, from 5 plants \\
\hline 6.2.10. Pedicel length & (PedL) & Average length, in $\mathrm{cm}$, of older flower from 5 plants, examining one inflorescence from each plant \\
\hline 6.2.18. Pods per plant & (PPlant) & Average from 5 plants at crop density \\
\hline Days to harvest $* * * *$ & (Dharv) & Time period between seed sowing and mature pods sampling \\
\hline \multicolumn{3}{|r|}{ Seed } \\
\hline 6.3.1. Seeds per pod & (SeedP) & Average number of seeds from one pod, selected from 5 plants \\
\hline 6.3.3. Seed weight & (SeedWh) & Weight of 100 seeds, in grams \\
\hline 6.3.5.1. Length & $($ SeedL) & Measured parallel to the hilum (mm) \\
\hline 6.3.5.2. Width & (SeedW) & $\mathrm{mm}$ \\
\hline 6.3.5.3. Height & $($ SeedH) & Height, measured from hilum to opposite side (mm) \\
\hline & & Qualitative \\
\hline \multicolumn{3}{|r|}{ Vegetative } \\
\hline Plant type ${ }^{* *}$ & (Planty) & $\begin{array}{l}\text { I. determinate bush, II. indeterminate straight, III. indeterminate crawling, IV. } \\
\text { indeterminate climbing. }\end{array}$ \\
\hline & & Inflorescence and Pod \\
\hline $\begin{array}{l}\text { 4.2.6. Pod color (from the fully } \\
\text { expanded immature pod) }\end{array}$ & (Pcol) & $\begin{array}{l}\text { Dark purple (1), carmine red (2), purple stripe on green (3), carmine tripe on green (4), pale red } \\
\text { stripe on green (5), dark pink (6), normal green }(7) \text {, shiny green (8), dull green to silver gray (9), } \\
\text { golden or yellow (10), pale yellow to white (11), other (12) }\end{array}$ \\
\hline 4.2.8. Pod cross-section & (Pcross) & Very flat (1), pear-shaped (2), round elliptic (3), figure of eight (4), other (5) \\
\hline $\begin{array}{l}\text { 4.2.9. Pod curvature (of the fully } \\
\text { expanded immature pod) }\end{array}$ & (Pcurv) & Straight (3), slightly curved (5), curved (7), recurving (9) \\
\hline 4.2.10. Pod suture string & (Psuts) & Stringless ( 0 ), few strings (3), moderately stringy (5), very stringy ( 7 ) \\
\hline $\begin{array}{l}\text { 4.2.11. Pod color at } \\
\text { physiological maturity }\end{array}$ & (Pcmat) & $\begin{array}{l}\text { Dark purple (1), red (2), pink (3), yellow (4), pale yellow with colored mottling or stripes (5), } \\
\text { persistent white (6) }\end{array}$ \\
\hline 6.2.12. Position of pods & $(\mathrm{PosP})$ & Base (1), center (2), top (3), combination of 1, 2, and 3 (4), other (5) \\
\hline 6.2.15. Pod beak position & (Pbeakp) & Marginal (1), non-marginal (2) \\
\hline 6.2.15. Pod beak orientation & (Pbeako) & Upward (3), straight (5), downward (7) \\
\hline 6.2.17.2 Dry pod color & (Dpcol) & $\begin{array}{l}\text { Dark purple (1), carmine red (2), purple stripe on green (3), carmine stripe on green (4), pale red } \\
\text { stripe on green (5), dark pink (6), normal green (7), shiny green (8), dull green to silver gray (9), } \\
\text { golden or deep yellow (10), pale yellow to white (11), other (12) }\end{array}$ \\
\hline \multicolumn{3}{|r|}{ Seed } \\
\hline 4.3.1. Seed coat patterns & (Scoatp) & $\begin{array}{l}\text { Absent }(0) \text {, constant mottled (1), striped (2), rhomboid spotted (3), speckled (4), circular mottling } \\
\text { (5), marginal color pattern (6), broad-striped (7), bicolor (8), spotted bicolor ( } 9 \text { ), pattern around } \\
\text { hilum (10), other (11) }\end{array}$ \\
\hline 4.3.2. Seed coat color & (Scoatdc) & $\begin{array}{l}\text { Black (1), brown, pale to dark (2), maroon (3), gray, brownish to greenish (4), yellow to greenish } \\
\text { yellow (5), pale-cream to buff (6), pure white (7), whitish (8), white, purple-tinged (9), chlorophyll } \\
\text { green (10). green to olive (11), red (12), pink (13), purple (14), other (15) }\end{array}$ \\
\hline 4.3.4. Brilliance of seed & (BSeed) & Matte (3), medium (5), shiny (7) \\
\hline 4.3.5. Seed shape & (SHseed) & Round (1), oval (2), cuboid (3), kidney-shaped (4), kidney pronounced (5), fastigiate trunk (6) \\
\hline 6.3.2. Apparent seed veining & (Aseed) & Absent (0), Present (1) \\
\hline
\end{tabular}




\subsection{Data Analysis}

A two-way analysis of variance (ANOVA) was performed for all quantitative traits to check the interaction between the genotype and the environment. Quantitative traits were summarized as mean, standard deviation, coefficient of variation, and minimum and maximum values. The qualitative characteristics were expressed on scales, as shown in Table 1 , and then graphically represented in the shape of stacked bar charts. A principal component analysis (PCA) was used to examine the association between the analyzed traits and the similarity among accessions. PCA was performed with all quantitative traits and the seed color, which was categorized using increasing values for darker colors. Data were analyzed using the software Statgraphics Centurion v.16 (Statpoint Technologies, Warrenton, VA, USA).

Additionally, for the quantitative traits, a Euclidean distance matrix based on standardized data was computed for clustering analysis by using the UPGMA (unweighted pair group method with arithmetic mean) method [28,29]. Goodness of fit of the resulting dendrogram was evaluated with the cophenetic correlation coefficient by using the Mantel test [30]. This analysis was made using the NTSYSpc2.0 software package (Applied Biostatistics Inc., Setauket, NY, USA).

\section{Results}

The seed morphology of the accessions was very variable in shape, size, and color (Figure 3). Five accessions, BGV1165, BGV3618, BGV3941, BGV4161, and BGV15856, exhibited a determinate growth habit; therefore, their plant height and yield-related traits differed significantly from those with indeterminate growth. For this reason, these accessions were excluded from the PCA.

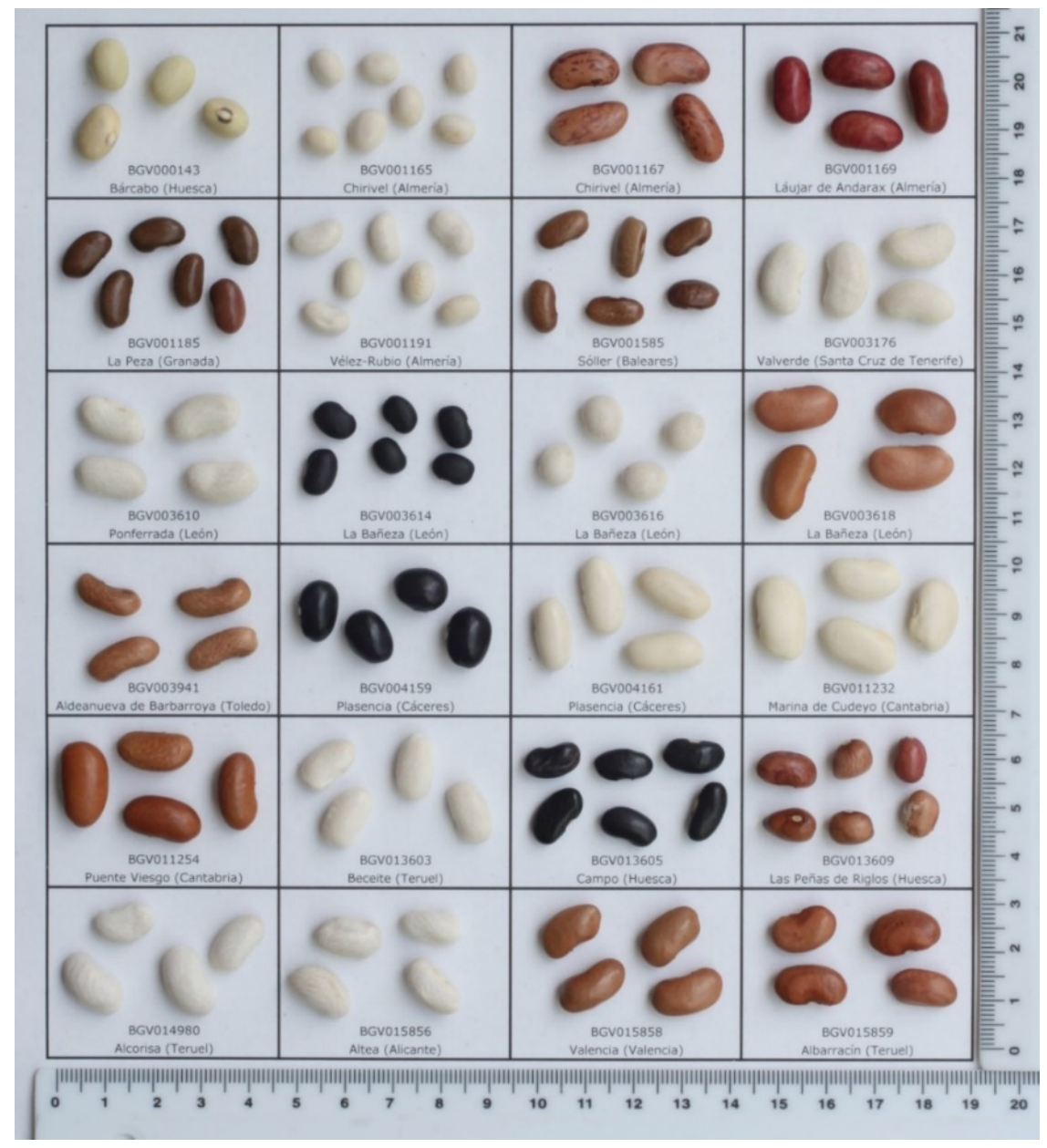

Figure 3. Seed morphology of the 24 P. vulgaris accessions. 
A two-way ANOVA was run to check the possible effect of the environment and the interaction between the genotype and the environment. The results indicated the existence of a significant effect of the environment and the interaction between the genotype and the environment for the majority of traits, especially those related to yield and its components (Table 2). For this reason, data of the two seasons were not merged and were analyzed separately in the PCA and basic statistics calculations.

Table 2. Two-way analysis of variance (ANOVA) of cultivar and cycle effects and their interactions for the parameters considered. Numbers represent F-values at the $5 \%$ confidence level.

\begin{tabular}{cccc}
\hline \multirow{2}{*}{ Dependent Variable } & \multicolumn{3}{c}{ Independent Variable } \\
\cline { 2 - 4 } & Cultivar & Cycle & Cultivar $\times$ Cycle \\
\hline LeafL (Leaflet length) & $36.42^{* * *}$ & $0.468 \mathrm{~ns}$ & $0.79 \mathrm{~ns}$ \\
Wcshe (Width of the central sheet) & $46.42^{* * *}$ & $1.479 \mathrm{~ns}$ & $0.97 \mathrm{~ns}$ \\
HypL (Hypocotyl length) & $135.54^{* * *}$ & $0.480 \mathrm{~ns}$ & $28.52^{* * *}$ \\
PlantH (Plant height) & $492.86^{* * *}$ & $3.24 \mathrm{~ns}$ & $0.28 \mathrm{~ns}$ \\
StemD (Stem diameter) & $40.29^{* * *}$ & $0.055 \mathrm{~ns}$ & $9.85^{* * *}$ \\
FlowBI (Flower buds per inflorescence) & $31.07^{* * *}$ & $0.09 \mathrm{~ns}$ & $2.57^{* * *}$ \\
PodL (Pedicel length) & $172.61^{* * *}$ & $2.05 \mathrm{~ns}$ & $3.40^{* * *}$ \\
InfloL (Inflorescence length) & $85.31^{* * *}$ & $14.21^{* * *}$ & $32.06^{* * *}$ \\
PedL (Pedicel length) & $70.89^{* * *}$ & $1.90 \mathrm{~ns}$ & $15.68^{* * *}$ \\
Pplant (Pods per plant) & $222.09^{* * *}$ & $3.92^{*}$ & $0.58^{\mathrm{ns}}$ \\
SeedP (Seed per pod) & $31.24^{* * *}$ & $7.09^{* *}$ & $1.07_{\mathrm{ns}}$ \\
SeedL (Length) & $237.02^{* * *}$ & 0.42 & $3.76^{* * *}$ \\
SeedW (Width) & $73.49^{* * *}$ & $1.14 \mathrm{~ns}$ & $7.47^{* * *}$ \\
SeedH (Height) & $71.75^{* * *}$ & $6.35^{*}$ & $3.93^{* * *}$ \\
Yield & $343.70^{* * *}$ & $2.27 \mathrm{~ns}$ & $4.22^{* * *}$ \\
\hline * $p<0.05^{* * *} p<0.01^{* * *} p<0.001^{* n \mathrm{~ns}}$ not significant.
\end{tabular}

\subsection{Principal Component Analysis and Cluster Analysis}

To find out which quantitative traits explained most of the variation in the set of accessions studied, a principal components analysis was carried out. The first three components explained $50.6 \%$ of the variation contained in the data $(21.7 \%, 16.7 \%$, and $12.7 \%$ for the first, second, and third components, respectively). The traits more positively correlated with the first PC component were those related to the yield (Yield) and its components (PodL, Pplant, SeedWh, SeedL, SeedW, SeedH) (Table 3, Figure 4).

The color of the seed coat (Scoatdc) and the apparent seed veining (Aseed) were negatively correlated. Traits related to the size of the leaves (LeafL and Wcshe) were best correlated with the second principal component. Some of the components of yield, pods per plant (Pplant), and seeds per pod (SeedP) also had high positive correlations, while the seed coat color (Scoatdc), seed weight (SeedWh), and seed shape (Shseed) were negatively correlated (Table 3, Figure 4).

The accessions analyzed were dispersed onto the two main components on the scatter plot of the PCA scores, indicating a large variability (Figure 5). It was also patent a separation of the accessions according to the size and color of their seeds. The accessions with black seeds were located at the top of the graph, mainly due to the seed coat color and to the larger size of their leaves, the greater number of seeds per pod, and the narrower shape of the seeds. On the left side of the graph, mostly cultivars with whitish seeds, lower yield, and without apparent seed veining were grouped. Within this group, there was also a remarkable separation according to the second PC, mainly related to the size of leaves and some components of yield. The accessions with brown seeds were also very dispersed, but with a predominance on the right side of the graph, due to their higher yield and larger number of seeds per pod of most cultivars of this type. There were three accessions with different seed coat color; one of them, BGV143, had yellow to greenish-yellow seeds. This accession had very low yield and was located in the lower part of the graphic. Contrarily, BGV1169, with maroon seed coat, was highly productive and grouped with the brown seeds. The accession BGV1185, with gray, brownish to greenish seed color, grouped with the whitish ones, with a very low yield (Figure 5). 
Table 3. Correlation coefficients between the first three principal components (PCs) and the morphological descriptors.

\begin{tabular}{cccc}
\hline & Component 1 & Component 2 & Component 3 \\
\hline LeafL & 0.09 & 0.39 & -0.08 \\
Wcshe & 0.08 & 0.38 & -0.14 \\
HypL & 0.09 & 0.04 & 0.17 \\
PlantH & -0.17 & -0.19 & 0.18 \\
StemD & 0.09 & 0.20 & -0.22 \\
Dflow & 0.11 & 0.05 & 0.12 \\
FlowBI & 0.13 & 0.14 & -0.07 \\
PodL & 0.22 & 0.07 & 0.26 \\
InfloL & 0.13 & -0.21 & -0.41 \\
PedL & 0.14 & -0.19 & -0.39 \\
Pplant & 0.22 & 0.27 & 0.14 \\
Dharv & 0.10 & -0.02 & -0.35 \\
SeedP & 0.03 & 0.35 & 0.19 \\
SeedWh & 0.36 & -0.25 & 0.04 \\
SeedL & 0.33 & -0.18 & 0.28 \\
SeedW & 0.33 & -0.15 & -0.13 \\
SeedH & 0.35 & -0.22 & 0.02 \\
Scoatdc & -0.22 & -0.24 & 0.22 \\
SHseed & 0.20 & -0.23 & 0.23 \\
Aseed & -0.29 & -0.12 & 0.15 \\
Yield & 0.35 & 0.18 & 0.23 \\
\hline
\end{tabular}

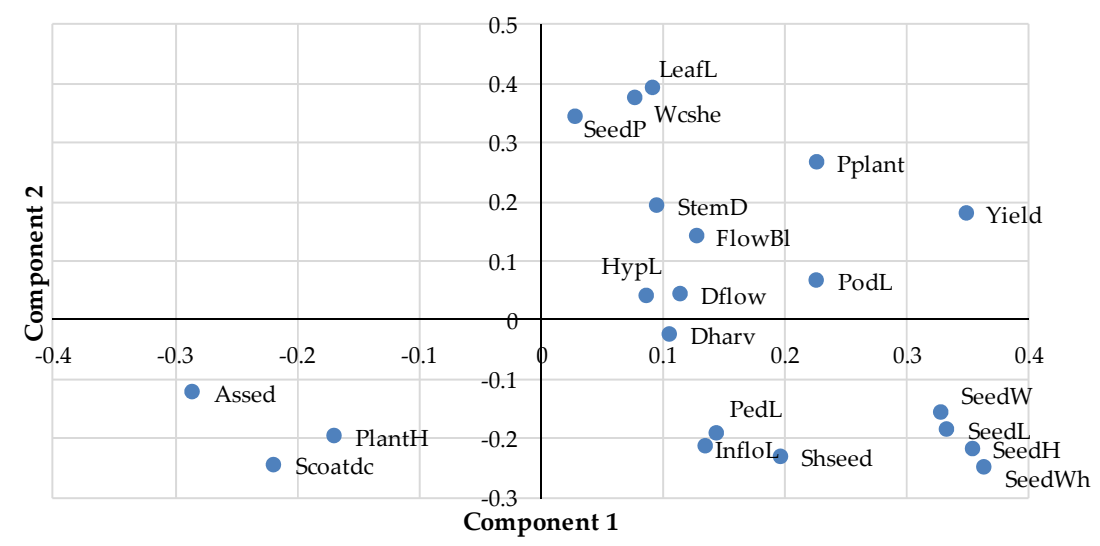

Figure 4. Loading plot of the principal component analysis (PCA) conducted with the quantitative traits analyzed in 24 accessions of $P$. vulgaris. Abbreviations are as in Table 1.

Regarding the cluster analysis, in the dendrogram obtained with the morphological traits by the UPGMA method, two main clusters can be observed (I and II, Figure 6). Cluster I includes the accessions encircled in yellow in Figure 5 and cluster II includes the ones encircled in green color. As expected, the accessions in the cluster analysis were grouped according to the traits related to yield (Yield) and its components (PodL, Pplant, SeedWh, SeedL, SeedW, SeedH). These traits were the most positively correlated with the first PC component in the PCA. In fact, the average values for these traits in the group of accessions included in cluster I (PodL $=15.44$; Pplant $=48.91$; SeedWh $=54.00$; SeedL $=14.16$; SeedW $=6.28$; SeedH $=8.18$; and Yield $=151.52$ ) were consistently higher than the ones for the accessions included in cluster II (PodL $=13.71$; Pplant $=22.83$; SeedWh $=40.56$; SeedL $=11.45$; SeedW $=5.63$; SeedH $=7.31$; and Yield $=41.25$ ). Also, as in the PCA analysis, the color of the seed was another relevant trait which contributed to the separation of the accessions. Thus, in cluster I, $75 \%$ of the accessions had seeds of brown color, while $55 \%$ of the seeds included in cluster II were white. The cophenetic correlation coefficient of the phenogram obtained from the 20 descriptors used in the analysis had a value of 0.86 . 


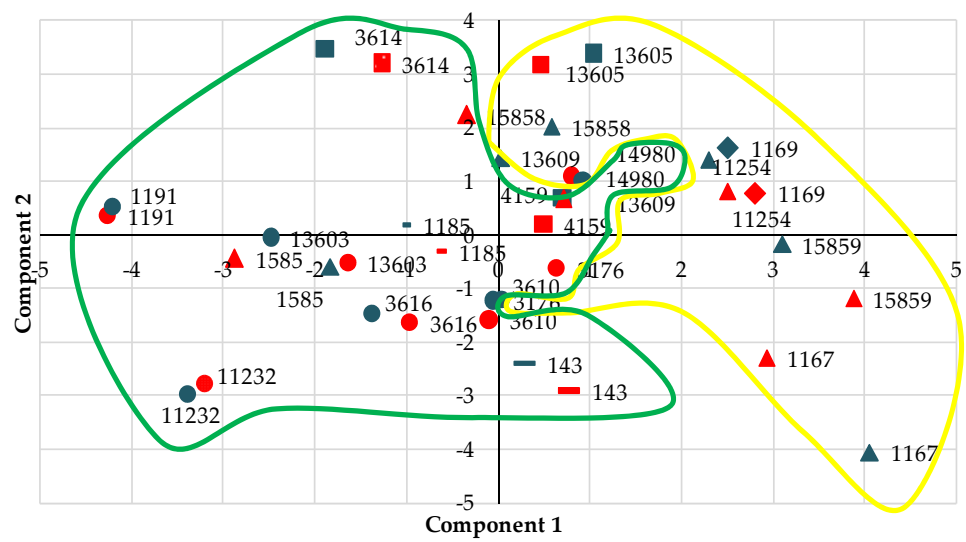

Figure 5. Scatter plot of the PCA scores. In red, scores of spring trial; in blue, autumn trial. Yellow to greenish-yellow seeds $(-)$, maroon seeds $(\diamond)$, grey, brownish to greenish seeds $(-)$, black seeds $(\square)$, brown, pale to dark seeds $(\Delta)$, whitish seeds $(\mathrm{O})$. Accessions included in the yellow and green areas correspond to the ones included in the two main clusters in Figure 6.

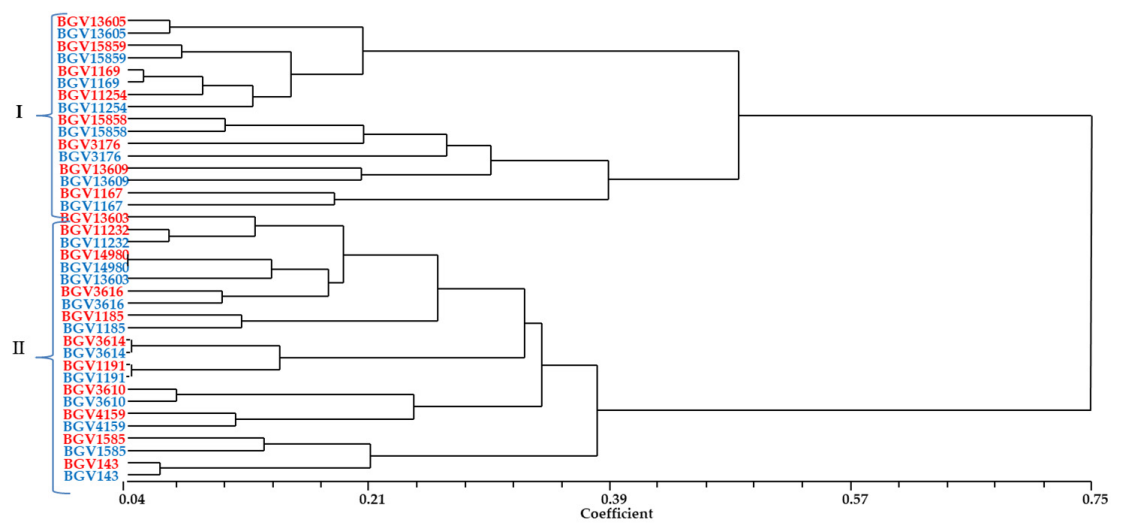

Figure 6. UPGMA (unweighted pair group method with arithmetic mean) phenogram of the 19 accessions of Phaseolus cultivated in two consecutive seasons based on 17 quantitative descriptors. Phenetic relationships were based on Euclidean pairwise distances estimates. I and II represent the two main clusters obtained. In red, scores of spring season; in blue, autumn season.

\subsection{Description of the Variability of the Whole Set of Accessions and of the Groups Established}

For the description of the variability found in the set of accessions, we grouped them according to the seed coat color, establishing three groups: black, brown, and whitish. The three accessions with different colors, BGV143, BGV1169, and BGV1185, are described separately, as well as the five accessions of determinate growth habit.

\subsubsection{Variability of the Whole Set of Accessions}

The whole set of accessions exhibited a high variability for most of the traits evaluated (Tables 4 and 5). Especially relevant was the variation for yield and number of pods per plant, which ranged from 2.8 to $242.8 \mathrm{~g}$ per plant and from five to 72 , respectively. The coefficient of variation for these traits was very high, 82.4 for yield and 59.4 for pods per plant. There was also a great variability for all traits related to inflorescence and some of the components of yield, with coefficient of variation (CV) values that ranged from 31.7 to 40.4 . The traits that showed lower variation were those related to vegetative characteristics and the height and width of the seeds; in these cases, the CV values ranged from 15.5 to 29. This trend was similar in the two trials performed. Regarding the qualitative traits recorded, there was little variation for pod cross-section, which was predominately pear-shaped, with pod curvature being straight in general, pod beak position being downward in most cases, and apparent seed veining being absent in general. For the other traits, there was high variation (Figures 7 and 8). 
Table 4. Descriptive statistics for quantitative traits in each of the established groups and the whole set of accessions (number of accessions). Autumn growing season. Units of quantitative traits are as defined in Table 1. CV—coefficient of variation.

\begin{tabular}{|c|c|c|c|c|c|c|c|c|c|c|c|c|c|c|c|c|c|c|c|}
\hline Accessions & & HypL & PlantH & StemD & LeafL & Wcshe & Dflow & Dharv & FlowBI & InfloL & PedL & Pplant & PodL & SeedP & SeedL & SeedWh & SeedH & SeedW & Yield \\
\hline \multirow[t]{5}{*}{ All accesions } & Mean & 10.53 & 1.70 & 5.18 & 16.51 & 11.48 & 42.54 & 110.25 & 4.17 & 7.65 & 3.77 & 29.15 & 14.26 & 5.09 & 12.96 & 47.14 & 7.77 & 5.94 & 74.53 \\
\hline & $S D$ & 3.05 & 0.69 & 1.26 & 3.76 & 3.22 & 6.65 & 23.08 & 1.42 & 2.42 & 1.55 & 17.31 & 4.28 & 1.87 & 3.07 & 17.29 & 1.20 & 1.14 & 61.41 \\
\hline & $\mathrm{CV}$ & 28.98 & 40.39 & 24.35 & 22.74 & 28.02 & 15.64 & 20.94 & 34.04 & 31.69 & 41.16 & 59.38 & 30.04 & 36.78 & 23.68 & 36.68 & 15.49 & 19.24 & 82.39 \\
\hline & Range & 2.80 & 0.32 & 2.75 & 9.80 & 5.40 & 28.00 & 71.00 & 1.00 & 2.71 & 1.10 & 5.00 & 5.60 & 1.00 & 7.03 & 17.20 & 4.72 & 3.64 & 2.80 \\
\hline & & 19.00 & 2.95 & 8.40 & 26.50 & 20.20 & 55.00 & 157.00 & 8.00 & 14.60 & 8.10 & 72.00 & 28.50 & 9.00 & 21.39 & 81.40 & 11.49 & 8.71 & 242.75 \\
\hline \multirow[t]{5}{*}{ Black (3) } & Mean & 10.73 & 1.85 & 5.50 & 20.26 & 15.84 & 41.00 & 117.33 & 4.05 & 8.29 & 4.23 & 43.47 & 12.66 & 6.17 & 10.45 & 33.89 & 7.40 & 5.76 & 92.49 \\
\hline & $S D$ & 1.23 & 0.32 & 0.70 & 3.53 & 2.51 & 5.57 & 29.69 & 1.43 & 1.88 & 2.06 & 16.97 & 3.36 & 2.20 & 1.74 & 15.67 & 1.01 & 1.19 & 62.28 \\
\hline & $\mathrm{CV}$ & 11.50 & 17.44 & 12.77 & 17.44 & 15.83 & 13.58 & 25.30 & 35.35 & 22.67 & 48.64 & 39.03 & 26.53 & 35.65 & 16.64 & 46.25 & 13.59 & 20.71 & 67.33 \\
\hline & Range & 9.1 & 0.99 & 4.2 & 16 & 11 & 36 & 92 & 2 & 5.9 & 1.9 & 23 & 8 & 1 & 7.5 & 19.2 & 5.62 & 4.38 & 34.52 \\
\hline & & 12.6 & 2.4 & 6.5 & 26.5 & 20.2 & 47 & 150 & 6 & 12.1 & 8.1 & 72 & 18.5 & 9 & 12.77 & 50.39 & 9.77 & 8.71 & 193.95 \\
\hline \multirow[t]{5}{*}{ Brown (8) } & Mean & 10.67 & 2.28 & 5.88 & 16.05 & 10.89 & 43.83 & 114.17 & 3.98 & 6.97 & 3.63 & 39.66 & 13.94 & 5.64 & 13.91 & 60.09 & 7.95 & 5.96 & 124.67 \\
\hline & $S D$ & 2.70 & 0.38 & 1.41 & 3.48 & 2.43 & 8.86 & 22.99 & 1.39 & 1.46 & 1.48 & 17.69 & 3.76 & 1.68 & 2.95 & 17.82 & 1.47 & 1.34 & 57.97 \\
\hline & $\mathrm{CV}$ & 25.30 & 16.82 & 23.99 & 21.68 & 22.28 & 20.22 & 20.14 & 34.88 & 20.98 & 40.84 & 44.62 & 26.99 & 29.75 & 21.23 & 29.65 & 18.47 & 22.56 & 46.50 \\
\hline & Range & 4.5 & 1.75 & 2.9 & 9.8 & 7.8 & 35 & 94 & 1 & 3.8 & 1.1 & 5 & 5.6 & 2 & 9.49 & 37.45 & 5 & 3.64 & 18.97 \\
\hline & & 14.5 & 2.95 & 8.4 & 22.4 & 19.2 & 55 & 143 & 6 & 10.9 & 7 & 65 & 21.2 & 8 & 18.69 & 81.4 & 10.74 & 8.16 & 242.75 \\
\hline \multirow{6}{*}{ Whitish (10) } & Mean & 11.64 & 1.80 & 4.52 & 16.32 & 11.55 & 45.29 & 112.14 & 3.89 & 6.57 & 3.20 & 26.30 & 15.92 & 5.02 & 12.52 & 39.56 & 7.44 & 5.52 & 54.07 \\
\hline & $S D$ & 2.93 & 0.20 & 0.84 & 2.92 & 2.78 & 2.69 & 21.07 & 1.49 & 2.89 & 1.32 & 10.51 & 5.25 & 1.89 & 2.84 & 12.86 & 1.06 & 0.92 & 38.14 \\
\hline & $\mathrm{CV}$ & 25.21 & 11.34 & 18.47 & 17.90 & 24.05 & 5.94 & 18.79 & 38.20 & 43.95 & 41.34 & 39.96 & 32.99 & 37.71 & 22.70 & 32.50 & 14.28 & 16.71 & 70.54 \\
\hline & Range & 7.8 & 1.2 & 2.75 & 11.1 & 7.2 & 41 & 87 & 2 & 2.71 & 1.1 & 8 & 9.8 & 2 & 7.41 & 19 & 4.72 & 3.89 & 15.14 \\
\hline & & 19 & 2.4 & 7.83 & 25 & 19.8 & 50 & 141 & 8 & 14.6 & 7.8 & 47 & 28.5 & 9 & 18.09 & 53.2 & 8.98 & 8.01 & 146.83 \\
\hline & Mean & 8.56 & 1.79 & 4.33 & 14.04 & 9.44 & 46 & 98.00 & 4.25 & 11.78 & 5.25 & 15.20 & 14.22 & 5.00 & 11.34 & 53.20 & 8.69 & 7.70 & 40.43 \\
\hline Yellow to & $S D$ & 0.74 & 0.02 & 0.69 & 3.48 & 1.23 & - & - & 1.71 & 1.87 & 1.37 & 3.49 & 1.20 & 0.71 & 0.58 & - & 1.15 & 0.38 & 9.29 \\
\hline greenish & $\mathrm{CV}$ & 8.65 & 1.34 & 16.03 & 24.80 & 13.08 & - & - & 40.18 & 15.91 & 26.14 & 22.98 & 8.47 & 14.14 & 5.16 & - & 13.23 & 4.90 & 22.98 \\
\hline \multirow[t]{3}{*}{ yellow (1) } & Range & 7.8 & 1.75 & 3.67 & 10.1 & 7.3 & 46 & 98 & 2 & 9 & 3.2 & 11 & 12.2 & 4 & 10.16 & 53.2 & 7.22 & 6.99 & 29.26 \\
\hline & & 9.5 & 1.81 & 5.3 & 20 & 10.9 & 46 & 98 & 6 & 13 & 6.1 & 20 & 15.2 & 6 & 12.06 & 53.2 & 11.49 & 8.11 & 53.2 \\
\hline & Mean & 6.18 & 1.80 & 6.04 & 17.68 & 13.50 & 37.00 & 157.00 & 4.33 & 7.67 & 4.05 & 12.00 & 13.95 & 4.50 & 12.23 & 38.60 & 7.90 & 5.62 & 20.84 \\
\hline Gray, & $S D$ & 1.80 & - & 1.41 & 1.15 & 1.09 & - & - & 1.21 & 0.82 & 0.61 & 3.39 & 0.90 & 0.84 & 0.90 & - & 0.32 & 0.34 & 5.89 \\
\hline brownish to & $\mathrm{CV}$ & 29.07 & - & 23.43 & 6.53 & 8.10 & - & - & 27.95 & 10.65 & 15.04 & 28.26 & 6.42 & 18.59 & 7.37 & - & 4.07 & 5.99 & 28.26 \\
\hline \multirow{2}{*}{ greenish (1) } & Range & 4.8 & 1.8 & 3.62 & 16 & 11.9 & 37 & 157 & 3 & 7 & 3.4 & 8 & 13 & 3 & 10.92 & 38.6 & 7.39 & 5.3 & 13.89 \\
\hline & & 9.2 & 1.8 & 7.13 & 19 & 14.6 & 37 & 157 & 6 & 9 & 5 & 16 & 15.3 & 5 & 13.74 & 38.6 & 8.33 & 6.26 & 27.79 \\
\hline \multirow{5}{*}{ Maroon (1) } & Mean & 13.66 & 2.26 & 4.84 & 19.29 & 14.67 & 51.00 & 110.00 & 3.80 & 6.48 & 2.34 & 51.20 & 17.42 & 5.60 & 15.10 & 63.70 & 8.56 & 7.46 & 182.64 \\
\hline & $S D$ & 0.55 & 0.19 & 0.44 & 1.51 & 2.93 & - & - & 0.45 & 0.38 & 0.35 & 7.01 & 3.10 & 0.89 & 0.59 & - & 0.29 & 0.39 & 25.02 \\
\hline & $\mathrm{CV}$ & 4.00 & 8.25 & 9.18 & 7.83 & 19.97 & - & - & 11.77 & 5.92 & 14.99 & 13.70 & 17.82 & 15.97 & 3.91 & - & 3.42 & 5.23 & 13.70 \\
\hline & Range & 12.8 & 2.08 & 4.33 & 17 & 9.5 & 51 & 110 & 3 & 6 & 2 & 44 & 12.1 & 4 & 14.14 & 63.7 & 8.09 & 6.77 & 156.95 \\
\hline & & 14.2 & 2.5 & 5.36 & 21.2 & 17.8 & 51 & 110 & 4 & 6.9 & 2.9 & 62 & 19.8 & 6 & 16.16 & 63.7 & 8.99 & 8.14 & 221.16 \\
\hline \multicolumn{20}{|c|}{ Determinate growth habit } \\
\hline \multirow{5}{*}{ Whithish (3) } & Mean & 6.97 & 0.54 & 4.76 & 15.70 & 9.98 & 41.00 & 102.00 & 4.63 & 8.74 & 4.97 & 13.36 & 10.36 & 3.41 & 12.06 & 38.33 & 7.58 & 6.00 & 19.44 \\
\hline & $S D$ & 3.02 & 0.13 & 0.51 & 4.77 & 2.59 & 3.61 & 4.58 & 1.45 & 2.78 & 1.58 & 4.07 & 2.92 & 1.08 & 3.54 & 20.86 & 1.30 & 0.94 & 13.69 \\
\hline & $\mathrm{CV}$ & 43.25 & 23.33 & 10.76 & 30.36 & 25.90 & 8.79 & 4.49 & 31.46 & 31.76 & 31.88 & 30.46 & 28.16 & 31.80 & 29.35 & 54.41 & 17.19 & 15.62 & 70.42 \\
\hline & Range & 2.8 & 0.335 & 4.2 & 9.8 & 5.4 & 38 & 98 & 2 & 4.23 & 2.8 & 6 & 6.5 & 2 & 7.03 & 17.2 & 5.22 & 4.68 & 2.80 \\
\hline & & 9.8 & 0.7 & 5.87 & 26 & 14 & 45 & 107 & 6 & 12.5 & 7.1 & 22 & 15.1 & 5 & 17.15 & 58.9 & 9.56 & 7.49 & 47.94 \\
\hline \multirow[t]{5}{*}{ Brown (2) } & Mean & 12.22 & 0.42 & 5.43 & 13.70 & 7.58 & 30.50 & 76.50 & 5.23 & 9.30 & 3.66 & 13.20 & 16.83 & 4.07 & 16.85 & 60.90 & 8.37 & 6.01 & 32.50 \\
\hline & $S D$ & 1.91 & 0.08 & $\begin{array}{l}2.45 \\
2.12\end{array}$ & 1.90 & 0.76 & 3.54 & 7.78 & $\begin{array}{l}1.17 \\
1.17\end{array}$ & 1.51 & $\begin{array}{l}0.00 \\
0.73\end{array}$ & 4.21 & $\begin{array}{l}10.00 \\
1.49\end{array}$ & 1.14 & $\begin{array}{l}10.00 \\
1.66\end{array}$ & 2.40 & $\begin{array}{l}0.07 \\
0.81\end{array}$ & 0.62 & 10.76 \\
\hline & $\mathrm{CV}$ & 19.49 & 16.35 & 27.16 & 12.77 & 9.55 & 10.71 & 9.49 & 19.43 & 16.58 & 16.50 & 60.16 & 9.24 & 28.53 & 10.84 & 4.06 & 10.11 & 10.71 & 63.35 \\
\hline & Range & 9 & 0.315 & 3.4 & 10.4 & 6.5 & 28 & 71 & 3 & 7.8 & 2.8 & 7 & 14.5 & 1 & 14.51 & 59.2 & 7.11 & 4.64 & 16.99 \\
\hline & & 15 & 0.55 & $\begin{array}{l}8.1 \\
8.1\end{array}$ & 16.1 & 9 & 33 & 82 & 6 & 12 & 4.8 & 21 & 19.2 & 5 & $\begin{array}{l}14.31 \\
21.39\end{array}$ & 62.6 & 9.67 & $\begin{array}{l}7.04 \\
\end{array}$ & 50.97 \\
\hline
\end{tabular}


Table 5. Descriptive statistics for quantitative traits in each of the established groups and the whole set of accessions (number of accessions). Spring growing season Units of quantitative traits are as defined in Table 1.

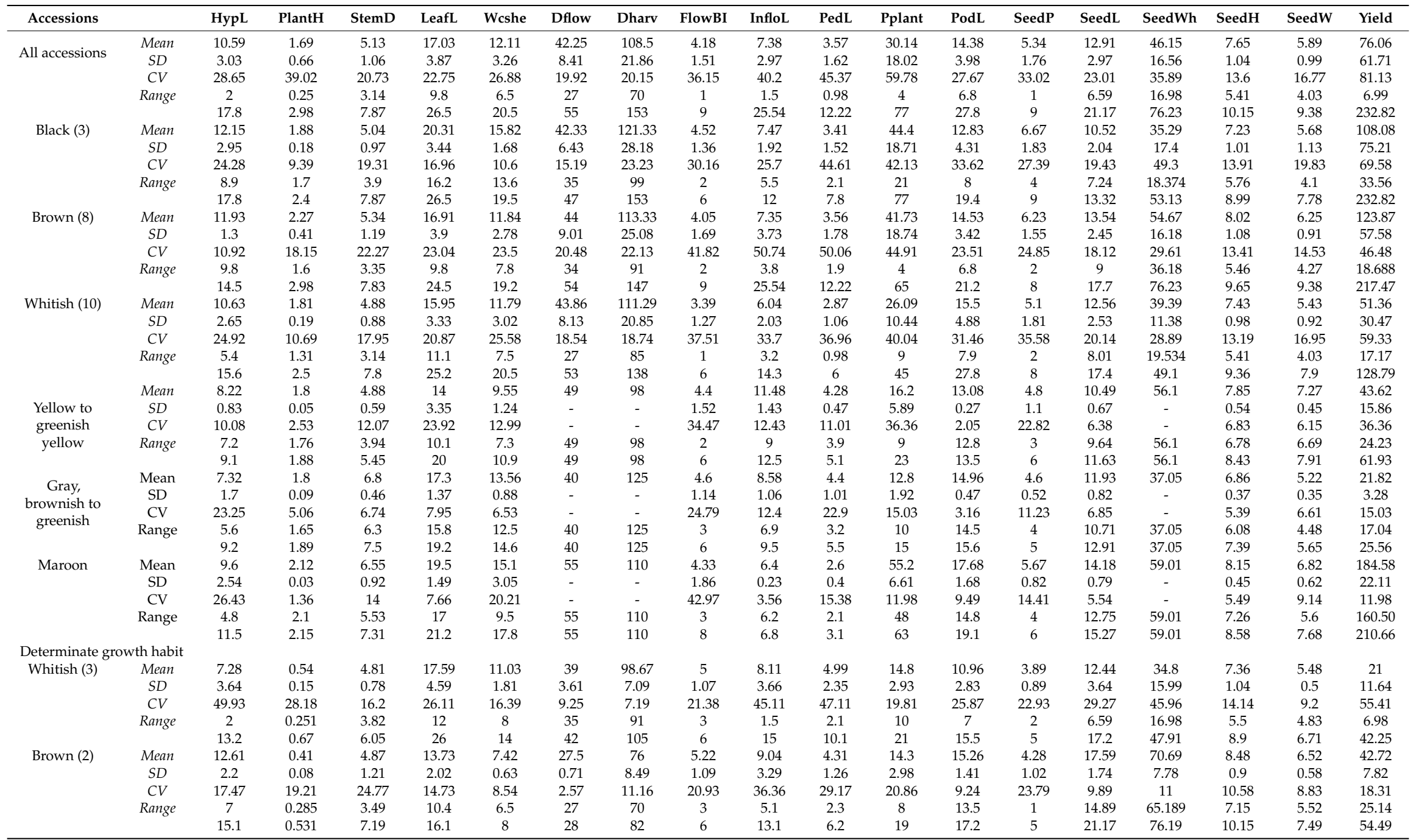



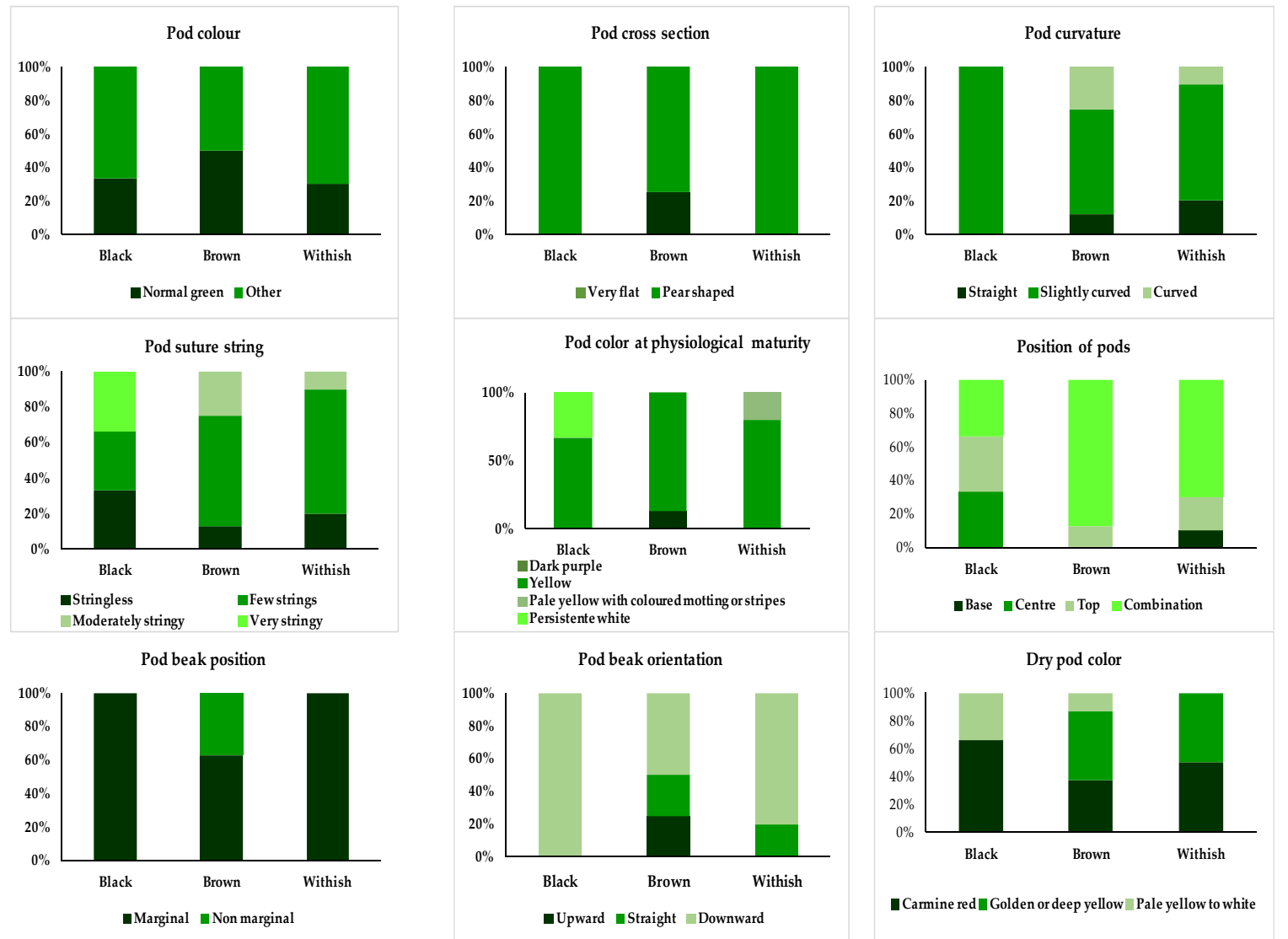

Figure 7. Pod traits of the $24 P$. vulgaris accessions evaluated.
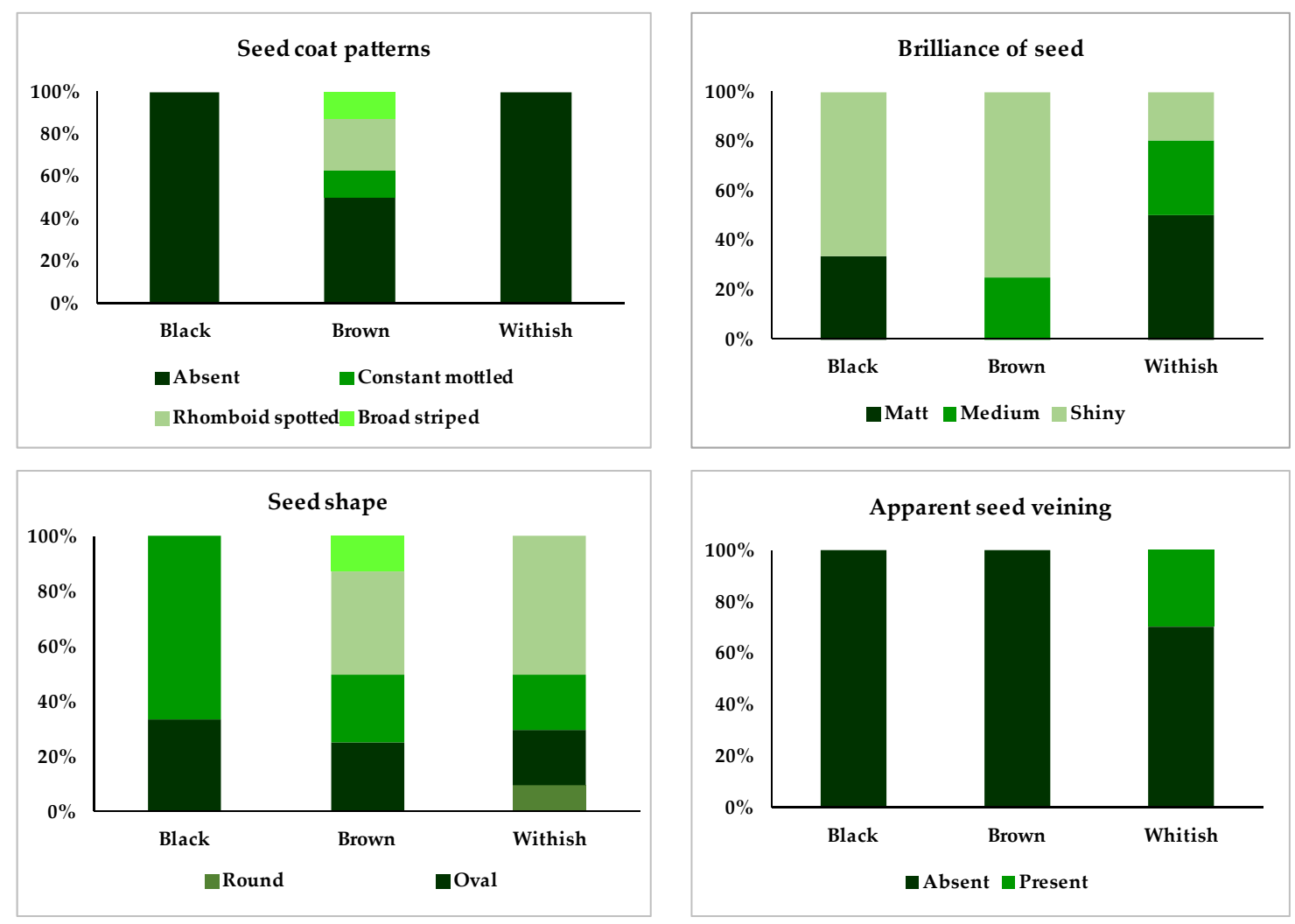

Figure 8. Seed traits of the 24 P. vulgaris accessions evaluated. 


\subsubsection{Description of the Three Accessions with Black-Colored Seeds}

Accessions with black seeds were the most leafy, with a higher mean value of central leaflet length and width, long inflorescences and peduncles, and a high number of pods per plant (Pplant) (on average 43.47 in the first cycle and 44.40 in the second, compared with the mean values for the whole set of accessions that were 29.15 and 30.14, respectively). These cultivars had the smallest seeds and, therefore, more seeds per pod than those from other groups (Tables 4 and 5). The average yield was high (92 in the first cycle, and 108 in the second), with a high coefficient of variation, as the yield ranged from 34 to 193 in the first cycle and from 33 to 239 in the second cycle. Qualitative traits (Figures 7 and 8 ) showed only a relatively smaller variation in comparison to the other group of cultivars, without any seed coat patterns or apparent seed veining, with seeds either matte or medium brilliant, and only two shapes, either oval or cuboid. No variation was registered for the trait pod beak position (marginal in all cultivars), pod beak orientation (upward), or pod cross-section (pear-shaped).

\subsubsection{Description of the Six Accessions with Brown-Colored Seeds}

Accessions with brown seeds included the most robust plants, with plant height ranging from 1.75 to $2.95 \mathrm{~m}$ in the first cycle, and from 1.6 to $2.98 \mathrm{~m}$ in the second one, with a larger stem diameter (Tables 4 and 5). The highest average yield was found for this group; the coefficient of variation for this characteristic was very high, $46 \%$ in both cycles, mainly due to the large variation in the number of pods per plant, ranging from five to 65 and from four to 65 , respectively. The group had the largest seeds, most notable in the weight of seeds ( 100 seeds weighed $60 \mathrm{~g}$ in the first cycle and $54 \mathrm{~g}$ in the second one). Among the qualitative characteristics (Figures 7 and 8), the seed coat pattern was outstanding and the most variable in comparison to the other groups. Furthermore, high variability was registered for the shape of seeds (including cultivars with ovoid, cuboid, and kidney-shaped seeds), the brilliance of seeds (medium and shiny), variable pod beak orientation (upward, straight, downward), and pod suture string (from stingless to very stringy). No variation was found for apparent seed veining, being absent in all cases.

\subsubsection{Description of the Seven Accessions with White-Colored Seeds}

Accessions with whitish seeds had generally smaller plants, with fewer pods per plant ( 26 in both cycles), smaller seeds, with a weight of $39 \mathrm{~g}$ for 100 seeds (in both cycles). The number of seeds per pod was also generally smaller and, therefore, the mean yield was much lower in comparison to the other accessions (54 g per plant in the first cycle and 51 in the second one), representing less than half of that registered for the group with brown seeds (Tables 4 and 5). However, the coefficient of variation of this trait was high, as some cultivars were much more productive than the others (e.g., BGV 3176 with $132 \mathrm{~g}$ per plant). Among the qualitative traits, the seed shape was more variable than in other groups; most of the cultivars had kidney-shaped seeds, but there were also some with cuboid, round, and oval seeds (Figure 8). Seeds coat patterns were absent, but seed brilliance varied from matte to shiny, and an apparent seed veining was detected only in this group.

\subsubsection{Description of the Accessions with Different Seed Colors and of the Accessions with a} Determinate Growth Habit

There were three accessions with seed coat color different from the ones described above. The accession BGV1169 had maroon seeds, BGV1185 exhibited gray, brownish-greenish seeds, and BGV143 had yellow to greenish-yellow-colored seeds. The three accessions differed in many traits. For vegetative traits, BGV1169 developed bigger leaves, both in length and width, and a short period from flowering to the harvest of the pods (59 days). It was also the most productive, with $182 \mathrm{~g}$ per plant, with higher values for the components of yield. In contrast, the accession BGV1185 was the one with the lowest yield ( $20.8 \mathrm{~g}$ per plant) and with the most prolonged period from flowering to harvest (120 days). The accession BGV143 had intermediate values for all traits, as well as outstanding 
inflorescence length and pedicel length; it showed the shortest period from flowering to harvest (52 days). The behavior of the three accessions was similar in both cycles. The growth habit of BGV143, BGV1169, and BGV1185 was climbing indeterminate. The color of the pod was light green for the cultivars BGV143 and BGV1185 and normal green for BGV1169. The cross-section and curvature of the pod were pear-shaped and slightly curved for all cultivars. BGV1169 did not present ventral suture in the sheaths, while the rest were very fibrous. The pods of the cultivars BGV1169 and BGV1185 at physiological maturity were yellow and pale yellow for BGV143 with colored mottling or stripes. The position of the pods in the plant was combined for BGV143 and BGV1185, while for BGV1169 the pods were concentrated in the center. The position and orientation of the apex of the pods were marginal and downward (downward). The dry pod color was golden or deep yellow (BGV1169) and carmine red (BGV143 and BGV1185). The seed coat patterns were absent for the three cultivars, and the seed brilliance was medium for BGV1169 and BGV143 and shiny in BGV1185. The seed shape was kidney-shaped (BGV1169 and BGV1185) and kidney pronged (BGV143). In all three cultivars, no ribs were observed in the seeds.

Regarding the accessions with determinate growth habit, there were two with brown seeds and three with whitish seeds. All of them had small plants, less than $0.5 \mathrm{~m}$ in height with narrow leaves. Accessions with brown seeds were very early and showed a short period from flowering to harvest (46 days). All accessions exhibited a high number of flower buds per inflorescence and low numbers of pods per plant and seeds per pod, giving rise to a low yield. Accessions with brown seeds were more productive than those with whitish seeds, because of their higher pod length, number of seeds per pod, and length and width of the seeds.

\section{Discussion}

Analysis of the complete set of accessions highlighted the great variability for most of the 32 characteristics evaluated. A high diversity was also reported in previous works on bean collections of Spanish origin [31,32]. It is also evident the diversity of types in terms of size, color, and shape of seeds, as well as for other characteristics related to the main differences between the two gene pools, the Mesoamerican and the Andean; they include the size and shape of the terminal trifoliolate leaflet, flower bracteoles, the presence or absence of stripes at the outer base of the flower standard, and the pod beak position. Our findings support results obtained by other authors who demonstrated that, in the Iberian Peninsula, after centuries of joint cultivation, a mixture of the two pools of germplasm occurred. This was already revealed, based on morphological studies, phaseolin protein patterns, and molecular markers [32,33]. The existence of both pools represents an added value to the Spanish germplasm. This high variability of Spanish accessions is of great value for their adaptation to the environmental conditions of both areas of domestication of this crop. Additionally, they may be used as a bridge for the transfer of genes between accessions belonging to both gene pools, as already suggested by Rodiño et al. [32].

The cluster and PCA analyses were congruent, and they clearly separated the accessions for their yield and yield components, mainly those related to pods and seeds, as well as their seed color. These characteristics are much more important in explaining the diversity of bean types in Spain, in contrast to other traits related to plant growth and earliness. The lack of grouping of accessions of different origin reflects a lack of regional differentiation, probably caused by transport by humans and seed exchange between farmers.

The high number of traits exhibiting interactions between the genotype and the environment, when cultivated in spring and autumn, is in agreement with previous reports $[34,35]$. Also, Nienhuis et al. [36] and Sills et al. [37] reported environmental effects in the expression of quantitative traits in different types of beans. This means that the best genotype for one environment may not be the best for another one and, therefore, specific types of beans must be developed for cultivation in different environments [38]. In our trial, the main differential environmental factor between the two growing seasons, autumn and spring, was the solar radiation, as shown in Figure 2, while the 
temperature and relative humidity were controlled in the greenhouse. Approximately $50 \%$ of the accessions did not show a great variation in yield when comparing the two seasons. However, the other accessions showed variation, most reaching higher yields in spring, in which solar radiation favors photosynthesis and, consequently, photoassimilation, regardless of the geographic origin of the accessions. The different response to the changing environment of the set of accessions studied in the present work is of great interest, and it can be exploited in breeding cultivars adapted to a broader range of environmental conditions.

The standard deviation values for seed weight, seed length, and seed width were higher than those reported by Escribano et al. [39], who studied a set of 66 landraces collected in Galicia (Spain). The same occurred for traits related to vegetative characteristics, such as length (LeafL) and width of the leaflet (Wcshe), and other traits of the pods and seeds. The range of variation for these traits was also higher in the set of accessions studied in the present work than in the germplasm studied by Rodiño et al. [32], which consisted of a group of 388 cultivars collected in the major production regions of the Iberian Peninsula and a core collection of 52 accessions constructed from the set of 388 cultivars.

The coefficient of variation compares the relative amount of variability between crop traits, and it is an excellent indicator of the exploitable variability for breeders. It is remarkable that high values were found in this work for many traits, especially those related to the yield and its components, as well as for other traits related to flowering and earliness. This high source of variability can be employed to develop varieties with very different characteristics, adapted to different environments, and also tailored to market preferences, in both groups of cultivars, with whitish and brown seeds, which are the most economically interesting groups. The accessions studied in this work were tested for their adaptation to abiotic stresses. Some of them showed good behavior under stress conditions. The results are being analyzed, and a manuscript is in preparation. Those data, together with the morphological description reported here, will help breeders select the most promising accessions to be used in breeding programs. The germplasm employed in this work is available upon request in the vegetable gene bank of the COMAV of the Polytechnic University of Valencia.

Author Contributions: Conceptualization, M.J.D. and M.B.; Methodology, S.A. and L.Y.; Software, J.T.; Validation, M.J.D. and O.V.; Formal Analysis, E.S.; Investigation, S.A. and J.T.; Resources, M.J.D. and O.V.; Data Curation, E.M.; Writing-Original Draft Preparation, S.A.; Writing-Review \& Editing, M.B., M.J.D. and O.V.; Visualization, J.T.; Supervision, M.B.; Project Administration, O.V.; Funding Acquisition, M.J.D. and O.V.

Funding: This research was funded by the Spanish "Ministerio de Economía, Industria y Competitividad", grant number RFP2015-00013-00-00 and cofinanced with FEDER funds.

Conflicts of Interest: The authors declare no conflict of interest. The funders had no role in the design of the study; in the collection, analyses, or interpretation of data; in the writing of the manuscript, and in the decision to publish the results.

\section{References}

1. Food and Agriculture Organization of the United Nations (FAO). FAOSTAT. Available online: http://faostat3.fao.org/browse/Q/QC/S (accessed on 10 January 2019).

2. Gepts, P.; Debouck, D.G. Origin, domestication and evolution of the common vean (Phaseolus vulgaris, L.). In Common Bean: Research for Crop Improvement; van Schoonhoven, A., Voysest, O., Eds.; CIAT: Wallingford, UK, 1991; pp. 7-43.

3. Gepts, P. Biochemical evidence bearing on the domestication of Phaseolus (Fabaceae) beans. Econ. Bot. 1990, 44, 28-38. [CrossRef]

4. Koening, R.; Gepts, P. Allozyme diversity in wild Phaseolus vulgaris: Further evidence for two major centers of genetic diversity. Theor. Appl. Genet. 1989, 78, 809-817. [CrossRef] [PubMed]

5. Tohme, J.; Gonzalez, D.O.; Beebe, S.; Duque, M. AFLP analysis of gene pools of a wild bean core collection. Crop Sci. 1996, 36, 1375-1384. [CrossRef]

6. Beebe, S.E.; Skroch, P.W.; Tohme, J.; Duque, E.; Pedraza, M.C.; Nienhuis, F. Structure of genetic diversity among common bean landraces of Middle American origin based on correspondence analysis of RAPD. Crop Sci. 2000, 40, 257-272. [CrossRef] 
7. Duran, L.A.; Blair, M.W.; Giraldo, M.C.; Macchiavelli, R.; Prophete, E.; Nin, J.C.; Beaver, J.S. Morphological and molecular characterization of common bean landraces and cultivars from the Caribbean. Crop Sci. 2005, 45, 1320-1328. [CrossRef]

8. Singh, S.P.; Gepts, P.; Debouck, D.G. Races of common bean (Phaseolus vulgaris, Fabaceae). Econ. Bot. 1991, 45, 379-396. [CrossRef]

9. Bitocchi, E.; Nanni, L.; Bellucci, E.; Rossi, M.; Giardini, A.; Zeuli, P.S.; Logozzo, G.; Stougaard, J.; McClean, P.; Attene, G.; et al. Mesoamerican origin of the common bean (Phaseolus vulgaris L.) is revealed by sequence data. Proc. Natl. Acad. Sci. USA 2012, 109, E788-E796. [CrossRef] [PubMed]

10. Ortwin-Sauer, C. The Early Spanish Men; University of California Press: Berkeley, CA, USA, 1966.

11. Brucher, O.B.; Brucher, H. The South American wild bean (Phaseolus aborigeneus Burk.) as ancestor of the common bean. Econ. Bot. 1976, 30, 257-272. [CrossRef]

12. Debouck, D.G.; Smartt, J. Bean. In Evolution of Crop Plants, 2nd ed.; Smartt, J., Simmonds, N.W., Eds.; Longman Scientific and Technical: Harlow, UK, 1995; pp. 287-296.

13. Santalla, M.; Rodiño, A.P.; De Ron, A.M. Allozyme evidence supporting southwestern Europe as a secondary center of genetic diversity for common bean. Theor. Appl. Genet. 2002, 104, 934-944. [CrossRef]

14. Pinheiro, C.; Baeta, J.P.; Pereira, A.M.; Dominguez, H.; Ricardo, C. Mineral elements correlations in a Portugese germplasm collection of Phaseolus vulgaris. Integrating Legume Biology for Sustainable Agricultura. In Proceedings of the 6th European Conference on Grain Legumes, Lisbon, Portugal, 12-16 Noviembre 2007; pp. 125-126.

15. Lioi, L.; Piergiovanni, A.R. European common bean. In Genetic and Genomic Resources of Grain Legume Improvement; Singh, M., Upadhyaya, H.D., Bisht, I.S., Eds.; Elsevier: Amsterdam, The Netherlands, 2013; pp. 11-40.

16. Boyer, J. Plant productivity and environment. Science 1982, 218, 443-448. [CrossRef]

17. Cramer, W.; Guiot, J.; Fader, M.; Garrabou, J.; Gatusso, J.P.; Iglesias, A.; Lange, M.A.; Lionello, P.; Llasat, M.C.; $\mathrm{Paz}, \mathrm{S}$; ; et al. Climate change and interconnected risks to sustainable development in the Mediterranean. Nat. Clim. Chang. 2018, 8, 972-989. [CrossRef]

18. Fita, A.; Rodriguez-Burruezo, A.; Boscaiu, M.; Prohens, J.; Vicente, O. Breeding and domesticating crops adapted to drought and salinity: A new paradigm for increasing food production. Front. Plant Sci. 2015, 6, 978. [CrossRef] [PubMed]

19. Santos, M.; Ribeiro, R.M.E.; Pimentel, C. Photosynthetic parameters and leaf water potential of five common bean genotypes under mild water deficit. Biol. Plant. 2009, 53, 229-236. [CrossRef]

20. Rosales, M.; Rodriguez-Valentin, R.; Olvera-Carrillo, Y.; Acosta-Gallegos, J.; Covarrubias, A. Physiological analysis of common bean (Phaseolus vulgarisL.) cultivars uncovers characteristics related to terminal drought resistance. Plant Physiol. Biochem. 2012, 56, 24-34. [CrossRef] [PubMed]

21. Beebe, S.; Rao, I.; Blair, M.; Acosta-Gallegos, J. Phenotyping common beans for adaptation to drought. Front. Physiol. 2013, 4, 35. [CrossRef]

22. Al Hassan, M.; Morosan, M.; Lopez-Gresa, M.; Prohens, J.; Vicente, O.; Boscaiu, M. Salinity-Induced variation in biochemical markers provides insight into the mechanisms of salt tolerance in common (Phaseolus vulgaris) and runner (P. coccineus) beans. Int. J. Mol. Sci. 2016, 17, 1582. [CrossRef]

23. Morosan, M.; Al Hassan, M.; Naranjo, M.; Loprez-Gresa, M.B.M.; Vicente, O. Comparative analysis of drought responses in Phaseolus vulgaris (common bean) and P. coccineus (runner bean) cultivar. EuroBiotech J. 2017, 1, 247-252. [CrossRef]

24. Arteaga, S.; Al Hassan, M.; Wijesinghe, C.; Yabor, L.; Llinares, J.; Boscaiu, M.; Vicente, O. Screening for Salt Tolerance in Four Local Varieties of Phaseolus lunatus from Spain. Agriculture 2018, 8, 201. [CrossRef]

25. IBPGR. Phaseolus vulgaris Descriptors. In Plant Production and Protection Division; FAO: Rome, Italy, $1982 ;$ p. 32.

26. Singh, S. A key for identification of different growth habits of Phaseolus vulgaris L. Annu. Rep. Bean Improv. Coop. 1982, 25, 92-94.

27. Rodrigo-Miguez, A.P. Caracterización Morfoagronómica y Bioquímica de Judía Común (Phaseolus Vulgaris L.) de España. Ph.D. Thesis, Universidad de Santiago de Compostela, Santiago, Spain, 2000.

28. Felsenstein, J. Numerical Taxonomy; W.H. Freeman \& Company: San Francisco, CA, USA, 1973.

29. Mohammadin, S.A.; Prasanna, B.M. Analysis of genetic diversity in crop plants-Salient statistical tools and considerations. Crop Sci. 2003, 43, 1235-1248. [CrossRef] 
30. Mantel, N. The detection of disease clustering and generalized regression approach. Cancer Res. 1967, 27, 209-220. [PubMed]

31. Gil, J.; De Ron, A. Variation in Phaseolus vulgaris in the Northwest of the Iberian Peninsula. Plant Breed. 1992, 109, 313-319. [CrossRef]

32. Rodiño, P.; Santalla, M.; De Ron, A.; Singh, S. A core collection of common bean from the Iberian peninsula. Euphytica 2003, 131, 165-175. [CrossRef]

33. Perez-Vega, E.; Campa, A.; De la Rosa, L.; Giraldez, R.; Ferreira, J. Genetic Diversity in a Core Collection Established from the Main Bean Genebank in Spain. Crop Sci. 2009, 49, 1377-1386. [CrossRef]

34. Vaid, K.; Gupta, V.; Singh, R. Stability analysis in dry bean. Crop Improv. 1985, 12, $28-31$.

35. Escribano, M.; De Ron, A.; Amurrio, J. Diversity in agronomical traits in common bean populaltions from northwestern Spain. Euphytica 1994, 76, 1-6. [CrossRef]

36. Nienhuis, J.; Singh, S. Combining ability analyses and relationships among yield, yield components and architectural traits in dry bean. Crop Sci. 1986, 26, 21-27. [CrossRef]

37. Sills, G.; Nienhuis, J. Field plot technique affects snap bean yield evaluation. J. Am. Soc. Hortic. Sci. 1993, 188, 672-674. [CrossRef]

38. Hosfield, G.; Uebersax, M.; Isleb, T. Seasonal and genotypic effects on yield and physico-chemical seed characteristics related to food quality n dry, edible beans. J. Am. Soc. Hort. Sci. 1984, 109, 182-189.

39. Escribano, M.; Santalla, M.; Casquero, P.; De Ron, A. Patterns of genetic diversity in landraces of common bean (Phaseolus vulgaris L.) from Galicia. Plant Breed. 1998, 117, 49-56. [CrossRef]

(C) 2019 by the authors. Licensee MDPI, Basel, Switzerland. This article is an open access article distributed under the terms and conditions of the Creative Commons Attribution (CC BY) license (http://creativecommons.org/licenses/by/4.0/). 